\title{
Randomised trial of high doses of stilboestrol and ethisterone therapy in pregnancy: long-term follow-up of the children
}

\author{
VALERIE BERAL AND LINDA COLWELL \\ From the Department of Medical Statistics and Epidemiology, London School of Hygiene and Tropical \\ Medicine
}

SUMmARY The 27-year follow-up is reported of 136 children whose mothers were involved in a randomised trial of high doses of stilboestrol and ethisterone therapy during pregnancy. The children were not contacted directly. Information about them was obtained from hospitals, general practitioners, and other official sources; and the persons who responded to our inquiries were unaware of who had been exposed to hormones in utero and whose mothers had received an inactive tablet. All children were traced. Urogenital anomalies were reported more frequently in the hormone-exposed than the unexposed children (14\% and $9 \%$ respectively). The earlier in pregnancy the therapy began, the higher the prevalence rate of abnormalities ( $\chi^{2}$ for trend, $\mathrm{p}<0.02)$. No malignant tumours were reported.

For males, the proportion reported to be married or living as married was lower in the exposed than in the unexposed group (32\% and $62 \%$ respectively). The proportion was lower the earlier in pregnancy hormonal exposure occurred and the higher the total hormone dose to which they were exposed $\left(\chi^{2}\right.$ for trend, $\left.p<0 \cdot 02\right)$. These findings suggest that some interference with sexual function may not be uncommon in males exposed to high doses of stilboestrol and ethisterone while in utero.

During the 1940s encouraging reports suggested that the administration of oestrogens and progestogens during pregnancy could substantially reduce fetal loss rates. ${ }^{1}$ Between 1940 and 1970 , but mostly in the 1950s, an estimated 500000 to 2000000 infants in the United States of America ${ }^{2}$ and 7800 in England and Wales ${ }^{3}$ had been exposed to exogenous sex hormones while in utero. In 1950 a randomised trial was set up in the United Kingdom to evaluate the effects of high doses of stilboestrol and ethisterone on the outcome of pregnancy of diabetic mothers. ${ }^{4}$ The findings, which were consistent with those from other trials, ${ }^{56}$ revealed identical rates of spontaneous abortion $(8 \%)$ and perinatal mortality $(23 \%)$ in the hormone-treated and control groups. It was concluded that such therapy in diabetic women did not reduce fetal loss rates.

Over the years it has become increasingly clear that in utero exposure to exogenous sex hormones may have adverse long-term effects. Masculinisation of the external genitalia of female children exposed in utero to progestins was first reported in $1958 .^{7}$ Soon after, Kaplan reported the feminisation of the external genitalia of a male infant whose mother took high doses of stilboestrol and progesterone. ${ }^{8}$ Since then a variety of urogenital abnormalities have been described, including hypotrophic testes and external genitalia, epididymal cysts, hypospadias, stenosis of the urethral meatus, and renal abnormalities in males; and abnormalities of the vagina, uterus, and Fallopian tubes in females. ${ }^{9-14}$ Unconfirmed reports have also suggested that in utero exposure to excessive exogenous or discordant sex hormones may affect personality, behaviour, and intelligence..$^{15-17}$

In 1971 Herbst and his colleagues reported the association between clear cell adenocarcinoma of the vagina in girls and in utero exposure to diethylstilboestrol during pregnancy. ${ }^{18}$ Since then 384 cases of adenocarcinoma of the vagina and cervix have been reported in the USA. ${ }^{19}$ The risk of vaginal or cervical adenocarcinoma occurring in a female exposed to stilboestrol during pregnancy is estimated to be between 0.14 and 1.4 per 1000 women up to the age of $24 .^{20}$ The risk is higher the earlier in intrauterine life the therapy was begun. ${ }^{19}$ Suggestions that in utero exposure to sex hormones may increase 
the risk of testicular cancer ${ }^{21}$ have not been subsequently confirmed. ${ }^{12}$

These reports of cancer and urogenital abnormalities have in general emanated from the United States of America. One case of vaginal cancer $^{22}$ and one of in-situ carcinoma of the cervix ${ }^{23}$ in exposed girls, and no studies of exposed males, have been reported in the United Kingdom. In this paper we report the follow-up for 27 years of 136 children whose mothers were involved in a randomised trial of stilboestrol and ethisterone therapy during pregnancy.

\section{Methods}

Details of the trial have been reported elsewhere. ${ }^{44}$ One hundred and sixty-one pregnancies in diabetic women were considered eligible and enrolled in the trial. Each pregnancy was randomly allocated to the 'hormone-treated' or 'non-hormone-treated' group. Women in both groups received tablets of identical appearance. The women and their attending obstetricians were unaware who were receiving hormones and who were not. Some women aborted before or soon after they began taking the tablets, or were later found to be not pregnant, and the 161 recruited pregnancies resulted in 136 births -70 in the hormone-treated group and 66 in the non-hormone-treated group.

The daily hormonal dosage schedule for the treated group was as follows:

Stage of pregnancy (weeks since last menstrual period)

Up to end of 19 th week 20th-23rd week inclusive 24th-27th week inclusive 28th-31st week inclusive 32nd week until delivery

$\begin{array}{cc}\text { Stilboestrol } & \begin{array}{c}\text { Ethisterone } \\ \text { ( } m \text { g per day) }\end{array} \\ \text { (mg per day) }\end{array}$

For each child, the total dose to which it was exposed and the duration of pregnancy when therapy began was calculated. Where no additional information was recorded it was assumed that therapy began three days after the tablets were dispatched and concluded the day before childbirth. All durations of pregnancy reported here are measured as weeks since the last menstrual period (LMP). A duration of pregnancy of ' 7 weeks' refers to any time during the week beginning 7 weeks 0 days after the LMP and ending 7 weeks 6 days after the LMP. For calculating average durations of pregnancy, the number of days are taken into account as well.
The follow-up procedure was identical to that described for the mothers. ${ }^{24}$ The children were not contacted directly, and all respondents to our inquiries were unaware whether the child was in the hormone-treated or non-hormone-treated group. We were notified of deaths, adoptions, and emigrations by the Office of Population Censuses and Surveys (OPCS). Copies of relevant death certificates were obtained. Post-mortem reports were available for the neonatal deaths, as part of the original study. For those who were still alive and had not been adopted or had not emigrated, a short questionnaire was sent to each subject's general practitioner (GP) asking about demographic factors and the occurrence of congenital or other abnormalities and tumours.

\section{Results}

At the time of entry into the trial the characteristics of the exposed and unexposed groups were comparable. Table 1 shows that the mean maternal ages and gravidities and the durations of pregnancy when therapy began were similar, as were the mean durations of pregnancy and birthweights.

All 136 births were traced by the OPCS. Two children had emigrated and three had been adopted (see Table 2). There were 18 stillbirths or deaths in

Table 1 Characteristics of the hormone-exposed and unexposed children at the time of the original trial

\begin{tabular}{|c|c|c|}
\hline & $\begin{array}{l}\text { Exposed to hormones } \\
(n=70)\end{array}$ & $\begin{array}{l}\text { Not exposed } \\
(n=66)\end{array}$ \\
\hline Mean maternal age & 29.1 & $28 \cdot 1$ \\
\hline Mean maternal gravidity & $2 \cdot 3$ & $1 \cdot 8$ \\
\hline $\begin{array}{l}\text { Mean no. of mother's previous } \\
\text { fetal losses or infant deaths }\end{array}$ & 0.7 & 0.5 \\
\hline $\begin{array}{l}\text { Mean no. of weeks since last } \\
\text { menstrual period when therapy } \\
\text { began }\end{array}$ & $12 \cdot 9$ & $13 \cdot 1$ \\
\hline $\begin{array}{l}\text { Mean duration of gestation (weeks } \\
\text { between last mestrual period } \\
\text { and delivery) }\end{array}$ & $36 \cdot 0$ & $36: 3$ \\
\hline Mean birthweight (kg) & $3 \cdot 3$ & $3 \cdot 2$ \\
\hline
\end{tabular}

Table 2 Follow-up status on 1 January 1979 of the children in the hormone exposed group and in the unexposed group

\begin{tabular}{lrc}
\hline & Exposed to hormones & Not exposed \\
\hline Alive-with questionnaire & 43 & 42 \\
$\quad$-without questionnaire & 4 & 4 \\
Dead-stillbirths or deaths in & 18 & 18 \\
$\quad$ first year & 2 & 0 \\
$\quad$-deaths after first year & 2 & 1 \\
Emigrated & 1 & 1 \\
Adopted & 2 & \\
TOTAL & & 66 \\
\hline
\end{tabular}


the first year of life in each group. These had been reported previously. ${ }^{4}$ No obvious differences in the recorded causes of death were evident-the majority were ascribed to prematurity, atelectasis, or maternal diabetes. On the other hand there were differences in the types of abnormalities described at post-mortem examination, and these will be discussed later. Subsequently two deaths have occurred, both in females and both in the hormone-treated group. One died of asthma at $1 \frac{1}{2}$ years of age, the other died in a motor vehicle accident at the age of 21 . Of the remaining 93 children who, according to the OPCS, were alive, not adopted, and resident in the UK, completed questionnaires were obtained from their GPs for $85(91 \%)$. Of the eight for whom no questionnaire was obtained, details of three could not be found on the files of their GP or area family practitioner committee; four were not currently registered with a GP (in all four cases the mother's GP informed us that the individual was alive); and in one case the GP was unwilling to complete our questionnaire.

There were 10 urogenital abnormalities in the 70 pregnancies exposed to hormones in utero and six in the 66 not exposed ( $14 \%$ and $9 \%$ respectively). Table 3 shows the types of urogenital abnormality in relation to the duration of pregnancy when the hormonal therapy began. The earlier the onset of therapy, the higher the proportion with abnormalities $\left(\chi^{2}\right.$ for trend $\left.=5.9 \mathrm{p}<0.02\right)$. The prevalence of other reported abnormalities was high, but no differences were evident between the exposed and unexposed groups. Overall, $14(20 \%)$ of the exposed and $15(23 \%)$ of the unexposed children had some abnormality recorded. Congenital heart disease was noted in three of the exposed and four of the unexposed group; limb reduction defects in one exposed and one unexposed child; and a meningocoele in one unexposed child.

Table 4 summarises the reported morbidity and other characteristics of the female offspring. The average age at follow-up was 27 . Two benign but no malignant tumours were reported. Both were in the treated group. One girl had a fibroadenoma of the breast, another had multiple naevi on the face necessitating surgical removal. The numbers consulting their GPs with infections of the urogenital tract were similar in both groups. Two girls consulted their GPs with infertility and both were in the treated group. Both finally conceived, one requiring bromocriptene therapy. The proportions married were similar in both groups. The average number of children born to married women in the treated group was somewhat lower than in the untreated group but the difference is not statistically significant.

No malignant or benign tumours were reported in the males (Table 5). More hormone-exposed than unexposed males consulted their GPs with infections of the urogenital tract, but the numbers were small. The proportion of males reported by GPs as married or living as married was lower in the hormone-exposed than in the unexposed group $\left(x^{2}=3.0 \mathrm{p}<0 \cdot 1\right)$. Moreover, the proportion of males married or living as married was related to the duration of pregnancy when hormone therapy began $\left(\chi^{2}\right.$ for trend $\left.=6.5 \mathrm{p}<0.02\right)$ and to the dose of stilboestrol to which they were exposed $\left(\chi^{2}\right.$ for trend $=7.9 \mathrm{p}<0.01$ ) (Table 6). The numbers were too small to disentangle whether the duration of pregnancy or the hormone dose was more strongly

Table 3 Urogenital abnormalities in the children in the hormone-exposed group and in the unexposed group, by duration of pregnancy when exposure first occurred

\begin{tabular}{|c|c|c|c|c|c|c|}
\hline $\begin{array}{l}\text { Duration of pregnancy } \\
\text { when exposure first } \\
\text { occurred } \\
\text { (weeks since LMP) }\end{array}$ & $\begin{array}{l}\text { No. of } \\
\text { children }\end{array}$ & $\begin{array}{l}\text { No. } \\
\text { abnormal }\end{array}$ & $\begin{array}{l}\text { Proportion } \\
\text { abnormal }\end{array}$ & Sex & $\begin{array}{l}\text { Alive } \\
\text { or dead }\end{array}$ & Details of abnormalities \\
\hline 10 weeks or less & 15 & 5 & 0.33 & $\begin{array}{l}\mathbf{F} \\
\mathbf{F} \\
\mathbf{M} \\
\mathbf{M} \\
\mathbf{M}\end{array}$ & $\begin{array}{l}\text { Dead } \\
\text { Dead } \\
\text { Dead } \\
\text { Alive } \\
\text { Alive }\end{array}$ & $\begin{array}{l}\text { Hermaphrodite } \\
\text { Double kidney and ureter } \\
\text { Enlarged kidney } \\
\text { Hydrocoele and inguinal hernia } \\
\text { Underdeveloped external genitalia }\end{array}$ \\
\hline 11 or 12 weeks & 23 & 4 & 0.17 & $\begin{array}{l}\mathbf{F} \\
\mathbf{M} \\
\mathbf{M} \\
\mathbf{M}\end{array}$ & $\begin{array}{l}\text { Alive } \\
\text { Dead } \\
\text { Dead } \\
\text { Alive }\end{array}$ & $\begin{array}{l}\text { Clitoral enlargement } \\
\text { Double kidney and ureter } \\
\text { Bilateral masses in the pelvis } \\
\text { Stricture of the urethral meatus }\end{array}$ \\
\hline 13 weeks or more & 32 & 1 & 0.03 & $\mathbf{M}$ & Alive & Inguinal hernia \\
\hline \multirow[t]{2}{*}{ Not exposed } & 66 & 6 & 0.09 & $\begin{array}{l}\mathbf{F} \\
\mathbf{M} \\
\mathbf{M}\end{array}$ & $\begin{array}{l}\text { Dead } \\
\text { Dead } \\
\text { Dead }\end{array}$ & $\begin{array}{l}\text { Bilateral ovarian cysts } \\
\text { Urethral valves and hydronephrosis } \\
\text { Single testis }\end{array}$ \\
\hline & & & & $\begin{array}{l}\mathbf{M} \\
\mathbf{M} \\
\mathbf{M}\end{array}$ & $\begin{array}{l}\text { Alive } \\
\text { Alive } \\
\text { Alive }\end{array}$ & $\begin{array}{l}\text { Inguinal hernia } \\
\text { Undescended testis } \\
\text { Cyst on the penis }\end{array}$ \\
\hline
\end{tabular}


Table 4 Morbidity and other characteristics of females exposed and not exposed to hormones in utero

\begin{tabular}{|c|c|c|}
\hline & $\begin{array}{l}\text { Exposed to hormones } \\
(n=18)\end{array}$ & $\begin{array}{l}\text { Not exposed } \\
(n=21)\end{array}$ \\
\hline Average age at follow-up & $27 \cdot 0$ & $27 \cdot 0$ \\
\hline Nos. with benign tumours reported & 2 & 0 \\
\hline $\begin{array}{l}\text { Nos. consulting with genitourinary } \\
\text { infections }\end{array}$ & 8 & 6 \\
\hline $\begin{array}{l}\text { Nos. consulting with amenorrhoea } \\
\text { (excluding that related to pregnancy } \\
\text { or oral contraceptive use) }\end{array}$ & 2 & 1 \\
\hline Nos. consulting with infertility & 2 & 0 \\
\hline Nos. reported to be married & 13 & 15 \\
\hline $\begin{array}{l}\text { Nos. of those married with } \\
\text { at least one child* }\end{array}$ & $10 / 13$ & $10 / 15$ \\
\hline Average no. of children & $1 \cdot 15$ & 1.62 \\
\hline $\begin{array}{l}\text { Nos. with history of } \\
\text { spontaneous abortion }\end{array}$ & 2 & 1 \\
\hline
\end{tabular}

* Married women only, excluding two unexposed whose GP did not know their pregnancy details.

Table 5 Morbidity and other characteristics of males exposed and not exposed to hormones in-utero

\begin{tabular}{lll}
\hline & $\begin{array}{l}\text { Exposed to hormones } \\
(n=25)\end{array}$ & $\begin{array}{l}\text { Not exposed } \\
(n=21)\end{array}$ \\
\hline $\begin{array}{l}\text { Average age at follow-up } \\
\begin{array}{l}\text { Nos. with benign or malignant } \\
\text { tumour reported }\end{array}\end{array}$ & 27.0 & 26.8 \\
$\begin{array}{l}\text { Nos. consulting with genitourinary } \\
\text { infections }\end{array}$ & 0 & 0 \\
$\begin{array}{l}\text { Nos. reported as married or } \\
\text { living as married }\end{array}$ & 8 & 1 \\
$\begin{array}{l}\text { Nos. reported to have fathered } \\
\text { at least one child* }\end{array}$ & $6 / 7$ & 13 \\
\hline
\end{tabular}

*Married men only, excluding one exposed and three unexposed males whose GP did not know their pregnancy details.

related to marriage rates. Although they had lower marriage rates, the married men who had been exposed to hormones in utero were somewhat more likely to be reported to have children of their own than were the unexposed.

\section{Discussion}

This study has certain advantages over others reported thus far. Firstly, the exposure to hormonal substances during pregnancy was allocated at random and follow-up was carried out with all participants being unaware if the individuals concerned were exposed or not. Only the study by Bibbo and her colleagues in Chicago ${ }^{10}$ is similarly randomised and 'double blind'. Secondly, the follow-up was virtually complete and information about dead children was obtained. The study by Bibbo et al was of live children, and only $42 \%$ of the original study population were included. Finally, detailed records of the pregnancies were maintained on standard forms, specially designed for the study, which included information on the clinical progress of the mother and the post-mortem findings on the children, where relevant. On the other hand, there were disadvantages: our study population was small, the mothers were diabetic, and information about the live children was obtained by writing to GPs rather than by direct interview and examination of the children. It is possible that the GPs were unaware of certain characteristics or illnesses in their patients. Also, some findings may be due to the fact that the mothers were diabetic. But neither of these factors could bias comparisons between the exposed and unexposed children.

An important feature of this study is the massive doses of hormones to which the children were exposed. The dose of stilboestrol ranged from $8.4 \mathrm{~g}$ to $24 \cdot 1 \mathrm{~g}$, averaging $17.9 \mathrm{~g}$. The range for ethisterone was $4.8 \mathrm{~g}$ to $23.0 \mathrm{~g}$, averaging $15.3 \mathrm{~g}$. In the Chicago study the children were exposed to $11 \mathrm{~g}$ of diethylstilboestrol and in other studies the diethylstilboestrol doses were considerably lower. ${ }^{25}$ The duration of pregnancy when therapy was first administered ranged from seven to 20 weeks after the LMP, averaging 12.9 weeks for the exposed children and $13 \cdot 1$ weeks for the unexposed.

The high rate of urogenital abnormalities noted here in children and young adults exposed to stilboestrol and ethisterone in utero is consistent with the findings from other studies. Since we included every reported urogenital abnormality, both in deceased and living children, the severity varies considerably. Not all are necessarily congenital in

Table 6 Percentage of males married or living as married by duration of pregnancy when hormonal exposure first occurred and total dose of stilboestrol to which they were exposed

\begin{tabular}{|c|c|c|c|c|c|c|c|}
\hline $\begin{array}{l}\text { Duration of pregnancy } \\
\text { when exposure } \\
\text { first occurred } \\
\text { (weeks since LMP) }\end{array}$ & $\begin{array}{l}\text { No. of } \\
\text { males }\end{array}$ & $\begin{array}{l}\text { No. } \\
\text { married }\end{array}$ & $\begin{array}{l}\text { Proportion } \\
\text { married }\end{array}$ & $\begin{array}{l}\text { Total dose of } \\
\text { stilboestrol } \\
\text { to which they } \\
\text { were exposed }\end{array}$ & $\begin{array}{l}\text { No. of } \\
\text { males }\end{array}$ & $\begin{array}{l}\text { No. } \\
\text { married }\end{array}$ & $\begin{array}{l}\text { Proportion } \\
\text { married }\end{array}$ \\
\hline 10 weeks or earlier & 6 & 0 & 0.0 & $20 \mathrm{~g}$ or more & 5 & 0 & 0.0 \\
\hline 11 or 12 weeks & 7 & 3 & 0.43 & 18.0 to $19.9 \mathrm{~g}$ & 11 & 3 & 0.27 \\
\hline 13 weeks or later & 12 & 5 & 0.42 & less than $18 \mathrm{~g}$ & 9 & 5 & 0.56 \\
\hline Not exposed & 21 & 13 & 0.62 & Not exposed & 21 & 13 & 0.62 \\
\hline
\end{tabular}


origin, but as it is unclear where the division between congenital and non-congenital should be, all are presented here. The most interesting is the hermaphrodite in the treated group, as this condition is extremely rare. The child died five hours after birth and at post mortem was found to have an ovary on one side and an ovo-testis on the other. In addition, bilateral Kobelt's cysts and Müllerian cysts were described. In utero exposure to hormones began eight weeks after the mother's LMP. The male described in Table 3 as having underdeveloped external genitalia underwent special investigations as a child because of this but no obvious cause was found. In utero exposure to hormones began seven weeks after the mother's LMP. His GP reports that he is now $6 \mathrm{ft} 1$ inch tall, weighs more than 18 stone, but still has small external genitalia. Although we have not seen him, the description is reminiscent of another male in the Chicago study reported by Gill et $a l^{11}$ as having 'bilateral hypotrophic testes ... and eunuchoid body habitus'.

Of all those exposed to hormones in utero, the hermaphrodite and the male with underdeveloped external genitalia were among the four in whom exposure began particularly early in pregnancy. The third child died and was found to have double kidneys at post mortem; and the fourth has been adopted and so no follow-up information could be obtained. The relationship of urogenital abnormalities to early onset of sex hormone therapy has not been reported previously in humans although animal experiments do suggest that fetal age is important. ${ }^{26}$ The other studies which reported on urogenital abnormalities were of living children only. ${ }^{9-14}$ It can be seen from Table 3 that three of the five abnormalities occurring when sex hormone therapy began 10 weeks or earlier after the LMP were in children who subsequently died. Had the deceased children been omitted, no relationship would have been detected between the abnormality rate and gestational age. This may account for other studies failing to detect a relationship similar to ours.

The high rate of other developmental abnormalities in the children is almost certainly due to the well-recognised increased risk of malformations in children of diabetic mothers. ${ }^{27}$ Differences between the exposed and unexposed children should not, however, be a consequence of the mother's diabetes. There have been suggestions that exposure to oral contraceptives and hormonal pregnancy tests in early pregnancy may increase the risk of congenital heart disease, limb reduction defects, and neural tube defects. ${ }^{28-31}$ We found no hint of such relationships, but our numbers are very small and hormone exposure tended to occur comparatively late in pregnancy. The young girl in the exposed group with multiple naevi of the face is, as an isolated observation, of little significance. However, she is of some interest, as Harlap and her colleagues reported that children exposed to sex hormones in early pregnancy had more haemangiomas, telangietasia and naevi than did unexposed children. ${ }^{32}$

That there was no case of vaginal cancer among the treated female children is not surprising, considering that its incidence is between 0.14 and 1.4 per 1000 exposed children. ${ }^{20}$ Our data are insufficient to permit detailed anlaysis of the effects of in utero hormone exposure on reproduction. Bibbo and her colleagues in Chicago reported a higher rate of oligomenorrhoea and of difficulty in becoming pregnant and a lower pregnancy rate in the hormone-exposed women than in the control group. ${ }^{10}$ Our findings tend to support theirs in that unfavourable symptoms and outcomes such as amenorrhoea with no obvious cause, infertility, and spontaneous abortion all clustered in the exposed group. Also the average family size was smaller in the exposed than in the unexposed group. Barnes and her colleagues failed to confirm the more frequent menstrual irregularities or infertility in hormone-exposed women, but they did note that unfavourable outcomes of pregnancy were more common in hormone-exposed than unexposed women. ${ }^{25}{ }^{33}$ The subjects in Barnes's studies were not randomised, they knew whether or not they had been exposed to hormones; and the hormone doses to which they were exposed were relatively low.

Information on marriage in males who were exposed to sex hormones in utero has not been reported previously, one reason being that the other studies were of younger men. The average age of the men in the Chicago study was $23^{1011}$ whereas the average age in our study at the time of follow-up was 27. Our information on marriage and cohabitation was that reported by the subject's GP, who is often uncertain about the personal lives of male patients. Nevertheless it seems unlikely that the comparisons between exposed and unexposed groups would be biased because the GPs did not know whether the individuals were exposed to hormones or not. It is unlikely that the relationship with pregnancy duration and hormone dose is fortuitous. But our observations need to be confirmed elsewhere, ideally by obtaining information in a more direct manner. If they are valid, they suggest that some interference with sexual function may not be uncommon among males exposed in utero to high doses of stilboestrol and ethisterone. Such disturbances could be related to anatomical factors such as the urogenital abnormalities described earlier. It is interesting that none of the four exposed males with urogenital 
abnormalities (who were still alive) were repörted to be married, but that all three of the unexposed males with urogenital abnormalities were reported to be married. These numbers are none the less too small to account for the low marriage rates in the exposed group, although it is possible that not all the existing urogenital abnormalities have been reported to us. Another explanation for the apparently low marriage rate is that in utero exposure to exogenous female sex hormones may affect normal male behaviour. There is considerable animal evidence to suggest that this is so. ${ }^{34}$ Human evidence, although fraught with difficulties in study design, seems to support the animal work. ${ }^{15} 17$

We thank the staff of the Office of Population Censuses and Surveys and the many GPs and hospital doctors for their help. The study was supported by the Medical Research Council.

Reprints from Dr. Valerie Beral, senior lecturer in epidemiology, Department of Medical Statistics and Epidemiology, London School of Hygiene and Tropical Medicine, Keppel Street, London WC1E 7HT.

\section{References}

${ }^{1}$ Smith WO. Diethylstilboestrol in the prevention and treatment of complications of pregnancy. Am J Obstet Gynecol 1948; 56: 821-34.

${ }^{2}$ Noller KL, Fish CR. Diethylstilboestrol usage. Med Clin North Am 1974; 58: 793-810.

${ }^{3}$ Kinlen LJ, Badaracco MA, Moffett J, Vessey MP. A survey of the use of oestrogens during pregnancy in the United Kingdom and of the genito-urinary cancer mortality and incidence rates in young people in England and Wales. J Obstet Gynaecol Br Commonwealth 1974; 81: 849-55.

${ }^{4}$ Conference on Diabetes and Pregnancy. The use of hormones in the management of pregnancy in diabetics. Lancet 1955; ii: 833-6.

s Dieckmann WJ, Davis ME, Rynkiewicz LM, Pottinger RE. Does the administration of diethylstilboestrol during pregnancy have therapeutic value? Am J Obstet Gynecol 1953; 66: 1062-81.

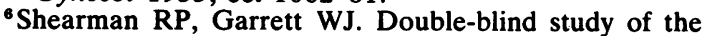
effect of 17-hydroxyprogesterone caproate on abortion rate. $\mathrm{Br}$ Med J 1963; i: 292-6.

${ }^{7}$ Wilkins L, Jones HW, Holman GH, Stempfel RS. Masculinization of female fetus associated with administration of oral and intramuscular progestins during gestation: non-adrenal female psuedohermaphrodism. J Clin Endocrinol Metab 1958; 18: 554-85.

${ }^{8}$ Kaplan NM. Male pseudohermaphrodism. N Engl J Med 1959; 261: 641-4.

${ }^{9} \mathrm{Bibbo}$ M, Al-Naqeeb M, Baccarini I et al. Follow-up study of male and female offspring of DES-treated mothers. $J$ Reprod Med 1975; 15: 29-32.

${ }^{10}$ Bibbo M, Gill WB, Azizi F et al. Follow-up study of male and female offspring of DES-exposed mothers. Obstet Gynecol 1977; 49: 1-8.

${ }^{11}$ Gill WB, Schumacher GFB, Bibbo M. Pathological semen and anatomical abnormalities of the genital tract in human male subjects exposed to diethylstilboestrol in utero. J Urol 1977; 117: 477-80.
${ }^{12}$ Cosgrove MD, Benton B, Henderson BE. Male genitourinary abnormalities and maternal diethystilboestrol. J Urol 1977; 117: 220-2.

${ }^{13}$ Mills JL, Bongiovanni AM. Effect of prenatal estrogen exposure on male genitalia. Pediatrics 1978; 62: 1160-5.

${ }^{14}$ Kaufman RH, Binder GL, Gray PM jr, Adam E. Upper genital tract changes associated with exposure in utero to diethylstilboestrol. Am J Obstet Gynecol 1977; 128: 51-9.

${ }^{15}$ Yalom ID, Green R, Fisk N. Prenatal exposure to female hormones. Effect on psychosexual development in boys. Arch Gen Psychiatry 1973; 28: 554-61.

${ }^{16}$ Ehrhardt AA. Behavioural effects of estrogen in the human female. Pediatrics 1978; 62: 1166-70.

${ }^{17}$ Meyer-Bahlburg HFL. Behavioural effects of estrogen treatment in human males. Pediatrics 1978; 62: 1171-7.

${ }^{18}$ Herbst AL, Ulfelder H, Poskanzer DC. Adenocarcinoma of the vagina. Association of maternal stilboestrol therapy with tumour appearance in young women. $N$ Engl J Med 1971; 284: 878-81.

${ }^{19}$ Herbst AL, Cole P, Norusis MJ, Welch WR, Scully RE. Epidemiologic aspects and factors related to survival in 384 Registry cases of clear cell adenocarcinoma of the vagina and cervix. Am J Obstet Gynecol 1979; 135: 876-83.

${ }^{20}$ Herbst AL, Cole P, Colton T, Robboy SJ, Scully RE. Age-incidence and risk of diethylstilboestrol-related clear cell adenocarcinoma of the vagina and cervix. $A m \mathrm{~J}$ Obstet Gynecol 1977; 128: 43-8.

${ }^{21}$ Linden G, Henderson BE. Genital tract cancers in adolescents and young adults. N Engl J Med 1972; 286: $700-1$.

${ }^{22}$ Monaghan JM, Sirisena LAW. Stilboestrol and vaginal clear-cell adenocarcinoma syndrome. $\mathrm{Br}$ Med J 1978; i: 1588-90.

${ }^{23}$ Shepherd JH, Dewhurst J, Pryse-Davies J. Cervical carcinoma-in-situ in women exposed to diethylstilboestrol in utero. $\mathrm{Br}$ Med J 1979; ii: 246.

${ }^{24}$ Beral V, Colwell L. Randomized trial of high doses of stilboestrol and ethisterone therapy in pregnancy: long-term follow-up of the mothers. Br Med J 1980; 280: 1098-101.

${ }^{25}$ Barnes AB, Coulton T, Gundersen $\mathrm{J}$ et al. Fertility and outcome of pregnancy in women exposed in utero to diethylstilboestrol. $N$ Engl J Med 1980; 302: 609-13.

${ }^{26}$ Nomura T, Kanzaki T. Induction of urogenital anomalies and some tumours in the progeny of mice receiving diethylstilboestrol during pregnancy. Cancer Res 1977; 37: 1099-104.

${ }^{27}$ Anonymous. Abnormal infants of diabetic mothers. Lancet 1980; i: 633-4.

${ }^{28}$ Janerich DT, Piper JM, Glebatis DM. Oral contraceptives and congenital limb-reduction defects. $N$ Engl $J$ Med 1974; 291 : 697-700.

${ }^{29}$ Heinonen OP, Slone D, Monson RR, Hook EB, Shapiro S. Cardiovascular birth defects and antenatal exposure to female sex hormones. $N$ Engl J Med 1977; 296: 67-70.

${ }^{30} \mathrm{Gal}$ I, Kirman B, Stern J. Hormonal pregnancy tests and congenital malformations. Nature 1967; $216: 83$.

${ }^{31}$ Greenberg G, Inman WHW, Weatherall JAC, Adelstein AM, Haskey JC. Maternal drug histories and congenital abnormalities. Br Med J 1977; ii: 853-6.

${ }^{32}$ Harlap S, Prywes R, Davies AM. Birth defects and oestrogens and progestagens on pregnancy. Lancet 1975; i: 682-3.

${ }^{33}$ Barnes AB. Menstrual history of young women exposed in utero to diethylstilboestrol. Fertil Steril 1979; 32: 148-53.

${ }^{34}$ Anonymous. Sexual behaviour and sex hormones. Lancet 1979; ii: $17-8$. 